\title{
Antimicrobial susceptibility profile of Campylobacter spp. isolated from different animal species in Minas Gerais
}

\section{Perfil de suscetibilidade a antimicrobianos de amostras Campylobacter spp isoladas de diferentes espécies animais em Minas Gerais}

\author{
Cristiane Pinheiro Toscano de BRITO $^{1}$; Elaine Maria Seles DORNELES ${ }^{1,2}$; Telma Maria ALVES ${ }^{1}$; \\ Ana Paula Reinato STYNEN ${ }^{1}$; Andrey Pereira LAGE ${ }^{1}$ \\ ${ }^{1}$ Universidade Federal de Minas Gerais, Escola de Veterinária, Departamento de Medicina Veterinária Preventiva, Laboratório de \\ Bacteriologia Aplicada, Belo Horizonte - MG, Brazil \\ ${ }^{2}$ Universidade Federal de Lavras, Departamento de Medicina Veterinária, Lavras - MG, Brazil
}

\begin{abstract}
Susceptibility pattern of 45 Campylobacter spp.isolates - 16 C. jejuni, eight C. coli, and 21 C. fetus isolated from different animal species in Brazil - to twelve antimicrobial agents was determined. All Campylobacter spp. isolates were susceptible to gentamicin, sulfadiazine, and sulfamethoxazole. C. jejuni and C. coli were also sensitive to chloramphenicol, whereas all $C$. fetus strains were susceptible to kanamycin. Cefoperazone showed the highest percentage of resistance among $C$. jejuni (68.75\%), followed by nalidixic acid (31.25\%), ampicillin (37.50\%), tetracycline (37.50\%), erythromycin (12.50\%), and kanamycin (6.25\%). Likewise, cefoperazone exhibited the highest percentage of resistance among C. coli (75.00\%), followed by nalidixic acid (50.00\%), tetracycline (50.00\%), erythromycin (37.50\%), ampicillin (12.50\%), and kanamycin (12.50\%). Among C. fetus strains, nalidixic acid showed the highest resistance rate $(85.71 \%)$, followed by cefoperazone $(71.43 \%)$, tetracycline (42.86\%), ampicillin (19.05\%), chloramphenicol (9.52\%), and erythromycin (4.76\%). Therefore, it was found that the majority of Campylobacter spp. isolated from animals was sensitive to gentamycin, chloramphenicol, kanamacyn, and sulfonamides; however, a high proportion of the strains showed reduced susceptibility to nalidixic acid, ampicillin, cefoperazone, and tetracycline. Moreover, $C$. coli and C. fetus isolates showed a high percentage of multidrug resistant strains. Keywords: Antimicrobial drug resistance. Campylobacter spp.. Brazil. Cattle. Pigs. Broilers. Marmosets. Dogs.
\end{abstract}

\section{Resumo}

O padrão de sensibilidade de 45 amostras de Campylobacter spp, incluindo 16 amostras de C. jejuni, 8 de C. coli e 21 C. fetus, isoladas de diferentes espécies de animais do Brasil, foi determinado para doze antimicrobianos. Todas as amostras de Campylobacter spp foram sensíveis à gentamicina, sulfadiazina e sulfametoxazol. C. jejuni e C. coli foram também sensíveis ao cloranfenicol, enquanto todas as amostras de C. fetus foram sensíveis à canamicina. Cefoperazona mostrou o maior percentual de resistência entre C. jejuni (68,75\%), seguido pelo ácido nalidíxico $(31,25 \%)$, ampicilina $(37,50 \%)$, tetraciclina $(37,50 \%)$, eritromicina $(12,50 \%)$ e canamicina $(6,25 \%)$. Similarmente, cefoperazona também exibiu o maior percentual de resistência entre as amostras de C. coli $(75,00 \%)$, seguido pelo ácido nalidíxico (50,00\%), tetraciclina (50,00\%), eritromicina (37,50\%), ampicilina (12,50\%) e canamicina (12,50\%). Entre os isolados de C. fetus, ácido nalidíxico apresentou maior taxa de resistência (85,71\%), seguido de cefoperazona (71,43\%), tetraciclina (42,86\%), ampicilina (19,05\%), cloranfenicol $(9,52 \%)$ e eritromicina $(4,76 \%)$. Assim, os nossos resultados mostraram que a maioria das amostras de Campylobacter spp isolados de animais foram sensíveis à gentamicina, cloranfenicol, canamicina e sulfonamidas. No entanto, uma proporção elevada das amostras apresentou susceptibilidade reduzida ao ácido nalidíxico, ampicilina, cefoperazona e tetraciclina. Além disso, C. coli e C. fetus mostraram uma alta porcentagem de amostras resistentes a múltiplas drogas.

Palavras-chave: Resistência a antimicrobianos. Campylobacter spp.. Brasil. Bovinos. Suínos. Frangos. Saguis. Cães.

Correspondence to:

Andrey Pereira Lage

Universidade Federal de Minas Gerais.

Av. Antônio Carlos, 6627

CEP 31270-901, Caixa Postal 567, Belo Horizonte, MG, Brazil

E-mail: alage@vet.ufmg.br

Received: 09/03/2016

Approved: 12/01/2017

\section{Introduction}

Campylobacter spp. are Gram-negative, nonspore forming, microaerophilic, curved or spiral rods responsible for important diseases in human and animals (DEBRUYNE et al., 2008) C. jejuni and C. coli are some of the major culture-confirmed bacteria associated with 
human gastroenteritis in the United States (CDC, 2013), and C. fetus subsp. fetus and C. fetus subsp. venerealis are important livestock pathogens, besides being human pathogens (ALVES et al., 2011).

Attention to Campylobacter infections has increased since they were recognized in 1970's as important human pathogens and public health issue, especially C. jejuni and, to a lesser extent, C. coli. (OLSON et al., 2008; CDC, 2013) Although the majority of the human cases of Campylobacter spp. gastroenteritis are related to self-limited diarrhea, severe sequels as reactive arthritis and Guillain-Barré syndrome may sporadically occur (OLSON et al., 2008). Humans are infected by C. jejuni or C. coli mainly through direct contact with carrier animals or consumption of contaminated food and water, poorly processed poultry meat and non-pasteurized milk (OLSON et al., 2008). C. fetus is a rare human pathogen frequently involved in systemic and extra-intestinal disease in patients with preexisting illnesses (WOO et al., 2002). In contrast to the secondary role in human infections, $C$. fetus is an important cause of abortion and infertility in cattle, being responsible for great economic losses (ALVES et al., 2011). Moreover, bacteria of the genus Campylobacter can be isolated from several domestic and wildlife animal species, as commensal microorganisms or causing a large number of non-reproductive diseases such as enteritis and mastitis (DEBRUYNE et al., 2008).

Antimicrobial treatment of human campylobacteriosis is usually not needed; however, for severe or long-lasting cases and for systemic infections it becomes mandatory (ADVICE FOR TRAVELERS, 2012). Erythromycin and azithromycin are the drugs of choice to treat $C$. jejuni and C. coli gastrointestinal infections in humans, but fluoroquinolones and tetracyclines are also recommended (ADVICE FOR TRAVELERS, 2012; DEKATE et al., 2013). The optimal treatment regimen for human C. fetus infection has not been determined, but gentamicin and imipenem are suggested as empirical therapy of choice and ampicilin, chloramphenicol, and fluoroquinolones could also be considered (TREMBLAY et al., 2003).

The resistance of Campylobacter spp. isolates, from both humans and animals, to different classes of antimicrobial agents such as quinolones, macrolides, aminoglycosides, tetracyclines, $\beta$-lactams, and sulfonamides has been widely reported (VAN DEN BOGAARD; STOBBERINGH, 2000; CHUMA et al., 2001; AVRAIN et al., 2003; TREMBLAY et al., 2003; MIRANDA; LAGE, 2007; ABAY et al., 2014;
DI GIANNATALE et al., 2014). Nonetheless, mainly the resistance to quinolones and macrolides has been considered an emerging public health hazard, due to its fast increase in the last decades (GIBREEL; TAYLOR, 2006; FITZGERALD et al., 2008; GARCIA-MIGURA et al., 2014). The high incidence of antibiotic resistance among Campylobacter spp. has led to an intensification of the discussion over the rational use of antimicrobial agents, especially in veterinary medicine, since their massive use, mainly as feed additives, has been related to the increase of drug resistance in Campylobacter spp. (JUNTUNEN et al., 2011; GARCIA-MIGURA et al., 2014; USUI et al., 2014).

Thus, the aim of the present study was to determine the antimicrobial susceptibility profile of 45 Campylobacter spp. isolates from different animal species in the State of Minas Gerais, Brazil.

\section{Materials and Methods}

\section{Bacterial strains and culture conditions}

A total of 45 Campylobacter spp. were used - 16 C. jejuni, eight C. coli, and 21 C. fetus strains from the collection of Laboratório de Bacteriologia Aplicada, Escola de Veterinária, Universidade Federal de Minas Gerais (UFMG) and Departamento de Microbiologia, Instituto de Ciências Biológicas, UFMG, isolated between 1977 and 2000 (LEITE, 1977; CARVALHO, 1992; LAGE, 1992; LAGE et al., 1992; STYNEN et al., 2003). C. jejuni strains were isolated from feces or rectal swabs of $\operatorname{dogs}(n=5)$, marmosets $(n=5)$, pigs $(n=3)$, broilers $(n=2)$, and calf ( $n$ $=1)$. C. coli strains were isolated from feces or rectal swabs of pigs $(n=6)$, broiler $(n=1)$, and calf $(n=1)$. C. fetus strains were isolated from feces of calves $(n=14)$ or from genital tract $(n=7)$ of adult cattle. All strains were isolated from animals from Minas Gerais, Brazil, and identified through routine laboratory methods (DEBRUYNE et al., 2008).

Campylobacter spp. isolates were cultured in brain heart infusion (BHI) agar (Difco, USA) supplemented with 10\% of defibrinated horse blood and incubated for $48 \mathrm{~h}$ at $37^{\circ} \mathrm{C}$ under microaerophilic conditions $\left(10 \% \mathrm{CO}_{2}, 5 \% \mathrm{O}_{2}, 85 \%\right.$ $\mathrm{N}_{2}$ ) (DEBRUYNE; GEVERS; VANDAMME, 2008).

\section{Antimicrobial susceptibility testing}

Minimum Inhibitory Concentration (MIC) was determined according to the Clinical and Laboratory Standards Institute (CLSI) VET01-A4 manual 
recommendations (CLSI, 2013a) for ampicillin (Life Technologies, Carlsbad, CA, USA), cefoperazone (Pfizer, New York, NY, USA), chloramphenicol (Life Technologies, Carlsbad, CA, USA), erythromycin (Gerbrás, Anápolis, GO, Brazil), gentamicin (Inlab, São Paulo, SP, Brazil), kanamycin (Inlab, São Paulo, SP, Brazil), nalidixic acid (Inlab, São Paulo, SP, Brazil), penicillin G (Inlab, São Paulo, SP, Brazil), streptomycin (Merck, Darmstadt, HE, Germany), sulfadiazine (Inlab, São Paulo, SP, Brazil), sulfamethoxazole (Sigma-Aldrich, St. Louis, MO, USA), and tetracycline (Inlab, São Paulo, SP, Brazil) in a dilution ranging from 0.0625 to $256 \mu \mathrm{g} /$ mL. Briefly, Mueller-Hinton agar (Difco, Sparks, MD, USA) plates supplemented with 5\% defibrinated horse blood plus the antimicrobial were inoculated with bacterial suspensions adjusted to turbidity equivalent to a $0.5 \mathrm{McF}$ arland standard and incubated for $48 \mathrm{~h}$ at $37^{\circ} \mathrm{C}$ under microaerophilic conditions.
Determination of the MIC was performed in duplicate and all antibiotics were tested with the reference strains Escherichia coli ATCC 25922, Pseudomonas aeruginosa ATCC 27853, and C. jejuni NCTC 11351 to ensure that the results were within acceptable limits of quality control for susceptibility testing (CLSI, 2013b). Furthermore, two Mueller-Hinton agar plates supplemented with $5 \%$ defibrinated horse blood, without antibiotics, were employed at the beginning of the antibiotic plate sequence, and two at the end of this sequence, as growth controls.

MIC breakpoints were set in accordance to the CLSI for C. jejuni / C. coli or Enterobacteriaceae (Table 1) (CHEN et al., 2010; CLSI, 2010, 2012, 2013b). Based on these criteria the strains were classified as resistant or sensitive to antimicrobials. However, the breakpoints to penicillin $\mathrm{G}$ and streptomycin were not defined by CLSI, and therefore the percentage of resistant strains could not be determined.

Table 1 - Minimal Inhibitory Concentration (MIC) breakpoints to determine antimicrobial susceptibility of Campylobacter spp. isolates

\begin{tabular}{|c|c|c|c|c|c|}
\hline \multirow{2}{*}{ Antibiotic } & \multicolumn{3}{|c|}{ MIC breakpoint } & \multicolumn{2}{|c|}{ Reference } \\
\hline & $\mathbf{S}^{\mathbf{a}}$ & $\mathbf{l}^{\mathbf{b}}$ & $\mathbf{R}^{\mathbf{c}}$ & Document & Strain \\
\hline Nalidixic acid & $\leq 8$ & - & $>16$ & CA-SFM ${ }^{d}$ & C. jejuni / C. coli \\
\hline Ampicillin & $\leq 8$ & 16 & $\geq 32$ & CLSI ${ }^{\mathrm{e}}$ - VET01-S2 & Enterobacteriaceae \\
\hline Kanamycin & $\leq 16$ & 32 & $\geq 64$ & CLSI - M100-S22 & Enterobacteriaceae \\
\hline Cefoperazone & $\leq 16$ & 32 & $\geq 64$ & CLSI - M100-S22 & Enterobacteriaceae \\
\hline Chloramphenicol & $\leq 8$ & 16 & $\geq 32$ & CLSI - VET01-S2 & Enterobacteriaceae \\
\hline Erythromycin & $\leq 8$ & 16 & $\geq 32$ & CLSI - M45-A2 & C. jejuni / C. coli \\
\hline Gentamycin & $\leq 2$ & 4 & $\geq 8$ & CLSI - VET01-S2 & Enterobacteriaceae \\
\hline Sulfadiazine & $\leq 256$ & - & $\geq 512$ & CLSI - VET01-S2 & Enterobacteriaceae \\
\hline Sulfamethoxazole & $\leq 256$ & - & $\geq 512$ & CLSI - VET01-S2 & Enterobacteriaceae \\
\hline Tetracycline & $\leq 4$ & 8 & $\geq 16$ & CLSI - M45-A2 & C. jejuni /C. coli \\
\hline
\end{tabular}

${ }^{\mathrm{a}}$ Susceptible; ${ }^{\mathrm{b}}$ Intermediate; ${ }^{\mathrm{c}}$ Resistant; ${ }^{\mathrm{d}}$ Antibiogram Committee of the French Society for Microbiology; ${ }^{\mathrm{e}}$ Clinical and Laboratory Standards Institute

Multidrug resistance was defined as resistance to three or more antimicrobial classes. The antimicrobial classes were as follows: (i) quinolones (nalidixic acid); (ii) macrolides (erythromycin); (iii) tetracycline (tetracycline); (iv) $\beta$-lactams (penicillin G, cefoperazone, and ampicillin); (v) aminoglycosides (gentamicin, streptomycin, and kanamycin); (vi) sulfonamides (sulfamethoxazole and sulfadiazine); and (vii) phenicols (chloramphenicol). Strains resistant to three or more antimicrobial groups were considered multidrug resistant. (MAGIORAKOS et al., 2012)

\section{Results}

The MIC range, MIC50 and MIC90 found for the 45 Campylobacter spp. studied strains, as well as the number of resistant strains to each antimicrobial agent tested are shown in figure 1. 


\section{C. jejuni}

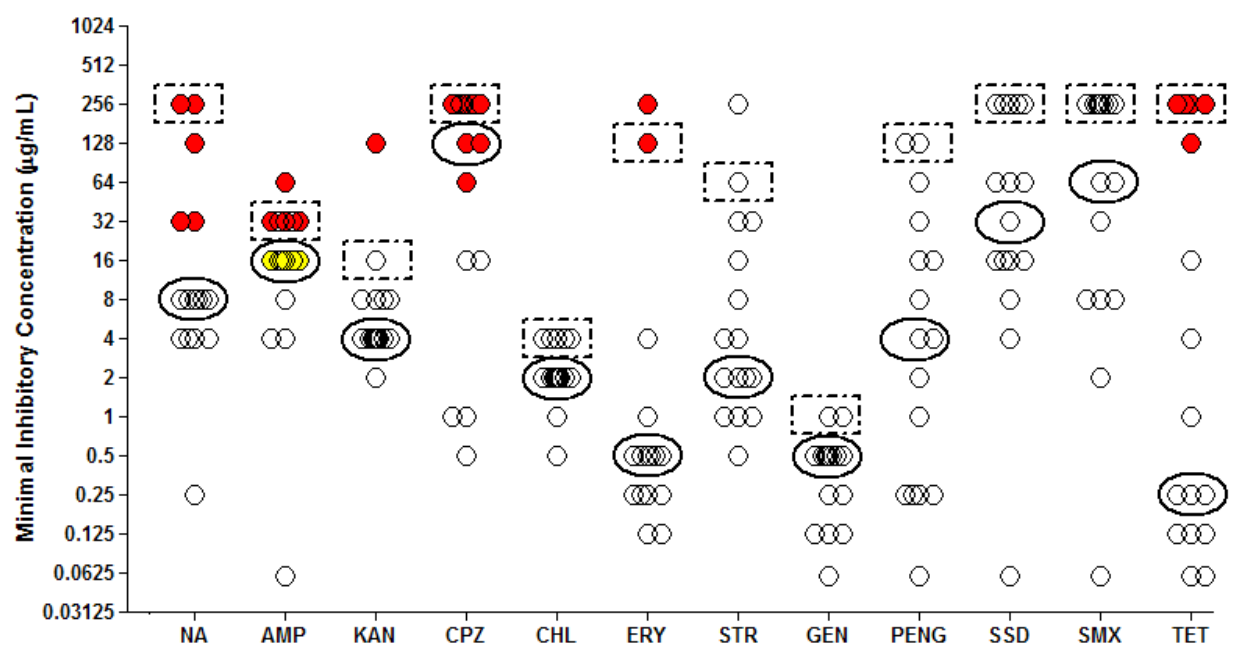

C. coli
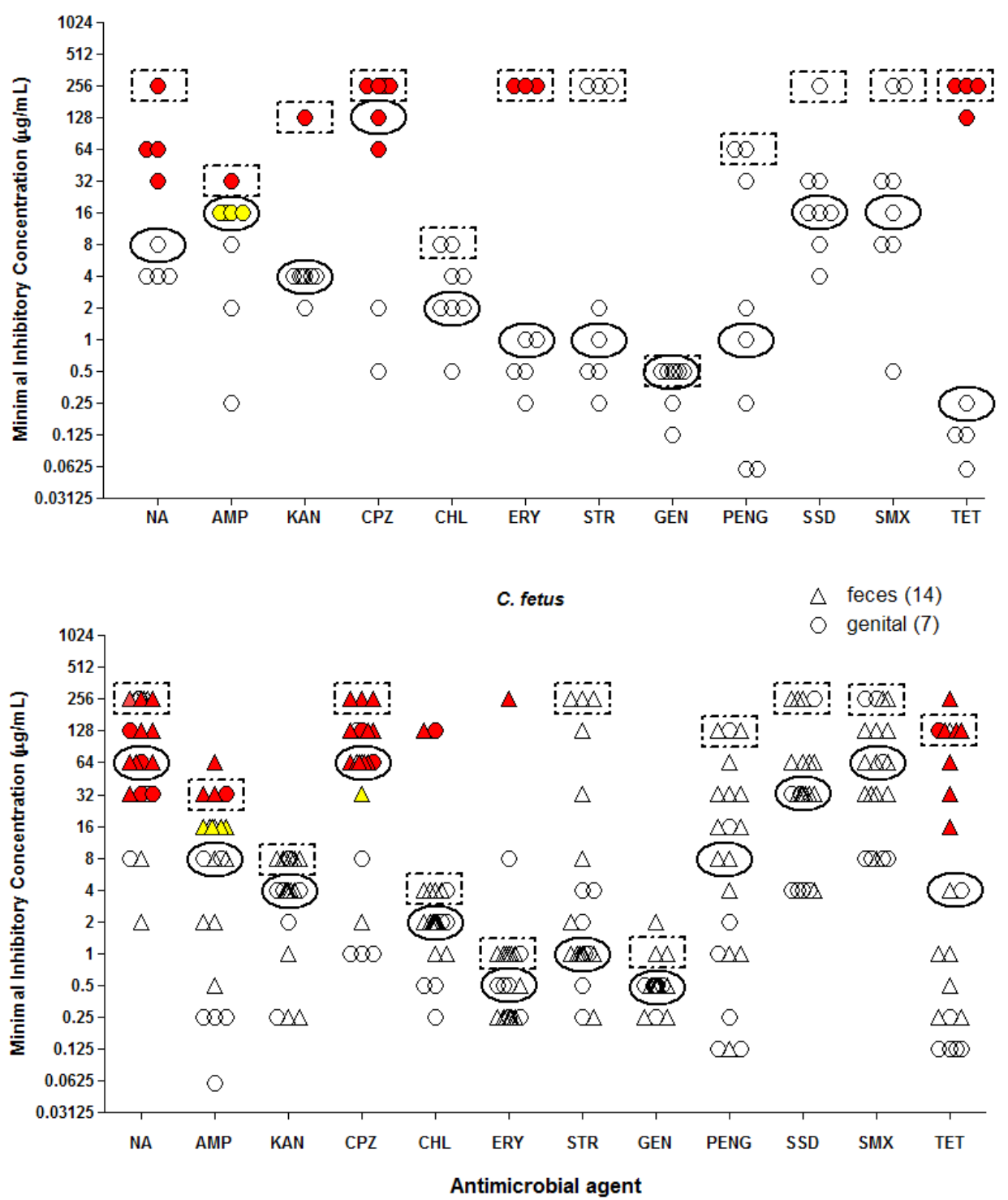

Figure 1 - Scatter plot of the Minimal Inhibitory Concentration (MIC) by the agar dilution method to nalidixic acid $(\mathrm{N}=\mathrm{A})$, ampicillin (AMP), kanamycin (KAN), cefoperazone (CPZ), chloramphenicol (CHL), erythromycin (ERY), streptomycin (STR), gentamycin (GEN), penicillin G (PENG), sulfadiazine (SSD), sulfamethoxazole (SMX), and tetracyclin (TET) of C. jejuni $(\mathrm{n}=16)$, C. coli $(\mathrm{n}=8)$, and C. fetus $(\mathrm{n}=21)$ strains isolated from animals in the state of Minas Gerais, Brazil. Resistant strains are shown in red symbols and intermediate susceptibility profile in yellow symbols. The ellipses indicate the $\mathrm{MIC}_{50}$ for each antimicrobial agent, while dotted rectangles indicate the $\mathrm{MIC}_{90}$ 
All Campylobacter spp. strains tested were susceptible to gentamicin, sulfadizine, and sulfamethoxazole (Figure 1). $C$. jejuni strains were also $100 \%$ sensitive to chloramphenicol. Cefoperazone was the antimicrobial that presented the lowest activity, against $C$. jejuni, with $68.75 \%$ (11/16) of resistant strains, followed by nalidixic acid [31.25\% (5/16)], ampicillin [37.50\% (6/16)], tetracycline [37.50\% (6/16)], erythromycin [12.50\% (2/16)], and kanamycin [6.25\% (1/16)] (Figure 1). Moreover, C. jejuni strains also exhibited an intermediate susceptibility profile to ampicillin [37.50\% (6/16)].

As observed in C. jejuni, all tested C. coli strains exhibited sensitivity to chloramphenicol. The antibiotic with the lowest activity against $C$. coli was cefoperazone, with $75.00 \%(6 / 8)$ of resistant strains, followed by nalidixic acid [50.00\% (4/8)], tetracycline $[50.00 \%(4 / 8)]$, erythromycin $[37.50 \%(3 / 8)]$, ampicillin $[12.50 \%(1 / 8)]$, and kanamycin $[12.50 \%(1 / 8)]$. Furthermore, $50.00 \%$ (4/8) of C. coli strains also showed an intermediate susceptibility profile to ampicillin.

Among C. fetus strains, the highest percentage of resistance was observed to nalidixic acid [85.71\% $(18 / 21)]$, followed by cefoperazone [71.43\% (15/21)], tetracycline [42.86\% (9/21\%)], ampicillin [19.05\% (4/21)], chloramphenicol $[9.52 \%(2 / 21)]$, and erythromycin $[4.76 \%$ $(1 / 21)]$. Intermediate susceptibility patterns to ampicillin and cefoperazone were observed in $28.57 \%(6 / 21)$ and $4.76 \%(1 / 21)$ of C. fetus strains, respectively. All C. fetus strains were susceptible to kanamycin.

The susceptibility profile of Campylobacter spp. strains tested for ten antimicrobials with established breakpoints is shown in table 2 .

Table 2 - Antimicrobial susceptibility profile of Campylobacter spp. strains isolated from animals in the state of Minas Gerais, Brazil

\begin{tabular}{|c|c|c|c|c|c|c|c|c|c|c|c|c|}
\hline Species & NA & AMP & KAN & CPZ & CHL & ERY & GEN & SSD & SMX & TET & $\mathbf{N}^{\mathbf{d}}$ & Profile \\
\hline C. jejuni & $\mathrm{R}^{\mathrm{a}}$ & $\mathrm{I}^{\mathrm{b}}$ & $\mathrm{S}^{c}$ & $\mathrm{R}$ & $S$ & $\mathrm{~S}$ & $S$ & $\mathrm{~S}$ & $S$ & $\mathrm{R}$ & 1 & 1 \\
\hline C. jejuni & $S$ & $\mathrm{R}$ & $S$ & $\mathrm{R}$ & $S$ & $\mathrm{R}$ & $S$ & $S$ & $S$ & $\mathrm{R}$ & 1 & 2 \\
\hline C. jejuni & $\mathrm{R}$ & $S$ & $S$ & $\mathrm{R}$ & $S$ & $\mathrm{R}$ & $S$ & $S$ & $S$ & $S$ & 1 & 3 \\
\hline C. jejuni & $S$ & $\mathrm{R}$ & $S$ & $\mathrm{R}$ & $S$ & $S$ & $S$ & $S$ & $S$ & $S$ & 3 & 4 \\
\hline C. jejuni & $S$ & I & $S$ & $\mathrm{R}$ & $S$ & $S$ & $S$ & $S$ & $S$ & $\mathrm{R}$ & 2 & 5 \\
\hline C. jejuni & $S$ & 1 & $\mathrm{~S}$ & $\mathrm{R}$ & $\mathrm{S}$ & $S$ & $S$ & $S$ & $\mathrm{~S}$ & $S$ & 2 & 6 \\
\hline C. jejuni & $\mathrm{R}$ & $S$ & $S$ & $S$ & $S$ & $S$ & $S$ & $S$ & $S$ & $S$ & 1 & 7 \\
\hline C. jejuni & $S$ & $\mathrm{R}$ & $S$ & $\mathrm{R}$ & $S$ & $S$ & $S$ & $S$ & $S$ & $\mathrm{R}$ & 1 & 8 \\
\hline C. jejuni & $S$ & I & $S$ & $S$ & $S$ & $S$ & $S$ & $S$ & $S$ & $S$ & 1 & 9 \\
\hline C. jejuni & $\mathrm{R}$ & $\mathrm{S}$ & $\mathrm{R}$ & $S$ & $S$ & $S$ & $\mathrm{~S}$ & $S$ & $\mathrm{~S}$ & $S$ & 1 & 10 \\
\hline C. jejuni & $S$ & $\mathrm{R}$ & $S$ & $S$ & $S$ & $S$ & $S$ & $S$ & $S$ & $S$ & 1 & 11 \\
\hline C. jejuni & $\mathrm{R}$ & $S$ & $S$ & $S$ & $S$ & $S$ & $S$ & $S$ & $S$ & $\mathrm{R}$ & 1 & 12 \\
\hline C. coli & $S$ & 1 & $S$ & $\mathrm{R}$ & $S$ & $\mathrm{R}$ & $\mathrm{S}$ & $S$ & $\mathrm{~S}$ & $\mathrm{R}$ & 1 & 1 \\
\hline C. coli & $\mathrm{R}$ & $\mathrm{R}$ & $\mathrm{R}$ & $\mathrm{R}$ & $S$ & $\mathrm{R}$ & $S$ & $S$ & $S$ & $R$ & 1 & 2 \\
\hline C. coli & $\mathrm{R}$ & $\mathrm{S}$ & $S$ & $\mathrm{R}$ & $S$ & $S$ & $S$ & $S$ & $S$ & $\mathrm{R}$ & 1 & 3 \\
\hline C. coli & $S$ & I & $S$ & $\mathrm{R}$ & $S$ & $S$ & $S$ & $S$ & $S$ & $\mathrm{R}$ & 1 & 4 \\
\hline C. coli & $\mathrm{R}$ & $\mathrm{S}$ & $S$ & $\mathrm{R}$ & $S$ & $S$ & $\mathrm{~S}$ & $S$ & $\mathrm{~S}$ & $S$ & 1 & 5 \\
\hline C. coli & $S$ & $\mathrm{~S}$ & $S$ & $S$ & $S$ & $S$ & $S$ & $S$ & $S$ & $S$ & 1 & 6 \\
\hline C. coli & $\mathrm{R}$ & I & $S$ & $S$ & $S$ & $S$ & $S$ & $S$ & $S$ & $S$ & 1 & 7 \\
\hline C. coli & $S$ & 1 & $S$ & $\mathrm{R}$ & $S$ & $\mathrm{R}$ & $S$ & $S$ & $S$ & $S$ & 1 & 8 \\
\hline C. fetus & $\mathrm{R}$ & $S$ & $S$ & $\mathrm{R}$ & $S$ & $S$ & $S$ & $S$ & $S$ & $\mathrm{R}$ & 3 & 1 \\
\hline C. fetus & $\mathrm{R}$ & I & $S$ & $\mathrm{R}$ & $S$ & $S$ & $S$ & $S$ & $S$ & $R$ & 2 & 2 \\
\hline C. fetus & $\mathrm{R}$ & $\mathrm{R}$ & $S$ & $\mathrm{R}$ & $S$ & $S$ & $S$ & $S$ & $S$ & $R$ & 2 & 3 \\
\hline C. fetus & $\mathrm{R}$ & 1 & $S$ & $\mathrm{R}$ & $\mathrm{R}$ & $S$ & $S$ & $S$ & $S$ & $\mathrm{R}$ & 1 & 4 \\
\hline C. fetus & $S$ & I & $S$ & $\mathrm{R}$ & $S$ & $\mathrm{R}$ & $S$ & $S$ & $S$ & $R$ & 1 & 5 \\
\hline C. fetus & $\mathrm{R}$ & $\mathrm{R}$ & $S$ & $\mathrm{R}$ & $\mathrm{R}$ & $S$ & $S$ & $S$ & $S$ & $S$ & 1 & 6 \\
\hline C. fetus & $\mathrm{R}$ & $S$ & $S$ & $S$ & $S$ & $S$ & $S$ & $S$ & $S$ & $S$ & 4 & 7 \\
\hline C. fetus & $\mathrm{R}$ & $\mathrm{S}$ & $S$ & $\mathrm{R}$ & $S$ & $S$ & $S$ & $S$ & $S$ & $S$ & 2 & 8 \\
\hline C. fetus & $\mathrm{R}$ & I & $S$ & $\mathrm{R}$ & $S$ & $S$ & $S$ & $S$ & $S$ & $S$ & 2 & 9 \\
\hline C. fetus & $\mathrm{R}$ & $\mathrm{R}$ & $S$ & 1 & $S$ & $S$ & $S$ & $S$ & $\mathrm{~S}$ & $S$ & 1 & 10 \\
\hline C. fetus & $S$ & $\mathrm{R}$ & $S$ & $\mathrm{R}$ & $S$ & $S$ & $S$ & $S$ & $\mathrm{R}$ & $S$ & 1 & 11 \\
\hline C. fetus & $\mathrm{S}$ & $\mathrm{S}$ & $\mathrm{S}$ & $\mathrm{S}$ & $\mathrm{S}$ & $\mathrm{S}$ & $\mathrm{S}$ & $\mathrm{S}$ & $S$ & $S$ & 1 & 12 \\
\hline
\end{tabular}

${ }^{\mathrm{a}}$ Resistant ${ }^{\mathrm{b}}$ Intermediate; ${ }^{\mathrm{c}}$ Susceptible; ${ }^{\mathrm{d}}$ Number of strains; ${ }^{\mathrm{e}}$ Profile highlighted in bold italics showed resistance to three or more antimicrobial groups and were considered multidrug resistant 
Three [14.29\% (3/21)] C. jejuni strains were multidrug resistant: two isolated from pigs and one from poultry. Among the observed multidrug-resistant $C$. coli strains $[37.50 \%(3 / 8)]$, two were isolated from pigs and one from calf. C. fetus strains exhibited the highest percentage of multidrug-resistant strains [47.62\% (10/21)]. Among C. fetus isolates from calf feces the percentage of multidrug resistant strains was $57.14 \%(8 / 14)$, whereas among the C. fetus isolated from genital tract $28.57 \%$ (2/7) were considered multidrug-resistant.

\section{Discussion}

The emergence of antibiotic resistance in Campylobacter spp. has been associated with the use of antimicrobials in veterinary medicine (THRELFALL et al., 2000; GARCIAMIGURA et al., 2014). Therefore, the present study investigated the susceptibility profile of C. jejuni, C. coli, and C. fetus isolated from different animal species in Minas Gerais, Brazil, to twelve antimicrobial agents, and observed that cefoperazone, nalidixic acid, and tetracycline were the antibiotics that exhibited the lowest activity against all Campylobacter spp. tested, whereas the highest rate of susceptible strains found was to chloramphenicol, gentamycin, sulfadiazine, and sulfamethoxazole.

Beta-lactam, including ampicillin and cefoperazone, was the antimicrobial class that showed the highest level of resistance among all Campylobacter spp. strains tested (Table 2). Since C. jejuni and C. coli spp. are universally resistant to cephalosporins (FITZGERALD et al., 2008) as well as cefoperazone, and this drug is regularly used in Campylobacter selective media (LAGE et al., 1992) to inhibit other bacteria, the excessive number of resistant strains to this antimicrobial was not an unexpected result; on the contrary, it confirms media with cefoperazone as a good choice for primary isolation of C. jejuni and C. coli. Furthermore, the high rate of resistance to cefoperazone also observed among $C$. fetus strains could be explained considering that all C. fetus strains isolated from feces samples were cultivated in medium containing this drug (LAGE et al., 1992), which is a surprising result, since C. fetus is not intrinsically resistant to cefoperazone. Reduced susceptibility, with a large number of resistant or intermediate patterns, especially amongst $C$. jejuni isolates, was also observed to ampicillin. Ampicillin resistance is of special clinical interest since this drug may be used for the treatment of severe human campylobacteriosis infections, particularly in children (GALLAY et al., 2007). C. jejuni and C. coli isolated from animals, mainly poultry, were broadly reported to be resistant to ampicillin (GALLAY et al., 2007; LEHTOPOLKU et al., 2010; ADZITEY et al., 2012; CHOKBOONMONGKOL et al., 2013; GIACOMELLI et al., 2014). Nevertheless, resistance to ampicillin among C. fetus strains has not been described, even for C. fetus isolated in the same region as the strains tested in the present study (Minas Gerais State, Brazil) (TREMBLAY et al., 2003; VARGAS et al., 2005; GALLAY et al., 2007; MIRANDA; LAGE, 2007). These differences are probably due to differences in the methodology used or in the origin of the strains, since a low-level agreement was observed for ampicillin in the comparison of agar dilution and agar disk diffusion methods (LUANGTONGKUM et al., 2007). Although there is no established breakpoint for penicillin $\mathrm{G}$ to Campylobacter spp., the wide range of MIC values observed as well as the high MIC50 and MIC90 values indicate a tendency to resistance to penicillin $\mathrm{G}$ among the tested C. jejuni, C. coli, and C. fetus strains (Figure 1). Moreover, a large number of those Campylobacter spp. strains were also resistant to other beta-lactams (cefoperazone and ampicillin), which strongly supports this trend of resistance to penicillin $\mathrm{G}$, as the production of beta-lactamases is the dominant mechanism of resistance to beta-lactam drugs and they are widely reported in Campylobacter spp. (WIECZOREK; OSEK, 2013).

Nalidixic acid, together with beta-lactam drugs, was the drug with the highest rates of resistance among the studied Campylobacter spp. strains, especially C. fetus strains, which are naturally resistant to nalidixic acid (Figure 1) (BURNENS et al., 1993). This nalidixic acid resistance may indicate resistance to other quinolones such as ciprofloxacin, although it was not assessed in the present study, since for $C$. jejuni and C. coli nalidixic acid resistance correlates well with resistance to other quinolone drugs (KINANA et al., 2006). Resistance to quinolones amongst Campylobacter spp. is a global concern and has increased and spread very quickly (FITZGERALD et al., 2008; GARCIA-MIGURA et al., 2014). Administration of quinolones, especially its subtherapeutic use in food animals, has been implicated as the force behind increase in resistance to quinolones in Campylobacter spp. isolates from humans and animals (JUNTUNEN et al., 2011; GARCIA-MIGURA et al., 2014; USUI et al., 2014). In Brazil, fluoroquinolones were used as growth-promoter, although this not allowed anymore, which could explain the great incidence of nalidixic acid resistant $C$. jejuni and 
C. coli strains observed in the present study (PAMVET-PR, 2005; SILVA; HOLLENBACH, 2010; SILVA et al., 2013). Moreover, this link is corroborated by poultry and pigs being, respectively, the main hosts of $C$. jejuni and C. coli, and quinolones being commonly use as feed additive in poultry and pork industries (PAMVET-PR, 2005; SILVA; HOLLENBACH, 2010).

Tetracycline was one of the three classes of antimicrobial drugs presenting the lowest activity against the tested Campylobacter spp. strains, with C. fetus strains showing the highest rate of resistance to it. This high level of resistance to tetracycline is probably a direct reflex of its intense use in veterinary medicine, especially in cattle (FDA, 2010). Indeed, cattle and sheep are the main hosts of $C$. fetus, which are found in the intestines of heathy animals and abundantly in their genital tract (LASTOVICA; ALLOS, 2008). The increase in resistance rates to tetracyclines of Campylobacter spp. is worrisome and has been constantly described, mainly in animal isolates (GALLAY et al., 2007; SAHIN et al., 2008; CHEN et al., 2010; LEHTOPOLKU et al., 2010; ADZITEY et al., 2012; CHOKBOONMONGKOL et al., 2013; DI GIANNATALE et al., 2014). Resistance to tetracycline has a clinical importance, since tetracycline is considered a second-line treatment for human Campylobacter spp. infections because of its low cost and toxicity (AARESTRUP et al., 2008; FITZGERALD et al., 2008). Furthermore, even though cattle are not considered the main sources of human campylobacteriosis, a recent study has demonstrated that their potential as source of infection in humans is underestimated (JONAS et al., 2015).

The obtained results showed a higher frequency of erythromycin resistance among C. coli strains, whereas it was less frequent among the tested C. jejuni and C. fetus strains. These findings are of public health importance as erythromycin is the first choice to treat human gastroenteritis caused by Campylobacter spp. (AARESTRUP et al., 2008; FITZGERALD et al., 2008). The higher incidence of erythromycin resistance among C. coli compared to other Campylobacter species may be due to the fact that the resistant $C$. coli strains were isolated from pigs, which are the only food animals for which erythromycin is allowed to be used as feed additive in Brazil (SILVA et al., 2013). Moreover, a higher frequency of erythromycin resistance has been reported worldwide among C. coli strains than C. jejuni strains (GIBREEL; TAYLOR, 2006; GALLAY et al., 2007; CHEN et al., 2010; LEHTOPOLKU et al., 2010).
For the tested aminoglycoside drugs, the findings were diverse. None of the tested Campylobacter spp. strains was resistant to gentamycin and only one C. coli was resistant to kanamycin (Figure 1). Susceptibility to gentamycin has been frequently described (LUANGTONGKUM et al., 2007; MIRANDA; LAGE, 2007; LEHTOPOLKU et al., 2010; ADZITEY et al., 2012; CHOKBOONMONGKOL et al., 2013; DI GIANNATALE et al., 2014; GIACOMELLI et al., 2014), being an important result, since gentamycin is commonly used in adherence and invasion assay (KONKEL; JOENS, 1989). Interestingly, the kanamycin susceptibility pattern observed in this study was also demonstrated to Campylobacter spp. strains also isolated in animals from Minas Gerais State, Brazil (MIRANDA; LAGE, 2007). Kanamycin is not an antibiotic usually included in susceptibility tests, but, differently from the observed to Campylobacter spp. from Minas Gerais, Luangtongkum et al. (LUANGTONGKUM et al., 2007) observed 36.38\% of resistance among Campylobacter spp. isolated from poultry. Although there is no breakpoint to streptomycin for either C. jejuni / C. coli or Enterobacteriaceae, the wide range of MIC values reported chiefly among $C$. jejuni and C. fetus strains (Figure 1) suggests that some strains may be resistant to this drug. However, it is important to consider that among the tested C. fetus strains the isolates from feces exhibited a wider MIC range ( 0.25 to $256 \mu \mathrm{g}$ / $\mathrm{mL}$ ) than strains isolated from genital tract ( 0.25 to $4 \mu \mathrm{g}$ / $\mathrm{mL}$ ), indicating that feces isolates had a greater tendency to streptomycin resistance. These results endorse the indication of streptomycin for treatment of bovine genital campylobacteriosis (LAGE; LEITE, 2000).

All of the C. jejuni and C. coli strains tested and most of the C. fetus strains were susceptible to chloramphenicol (Figure 1). This high susceptibility to chloramphenicol may be due to the prohibition of the use of this antibiotic in veterinary medicine in Brazil because of the risk of residues of this drug in meat, milk, and eggs (BRASIL, 1998). Hence, chloramphenicol as well as kanamycin and gentamycin could be suggested as options to treat human Campylobacter infections in Brazil. Likewise, the sulfonamides tested, sulfadizine and sulfamethoxazole, could be recommended to treat infections by Campylobacter spp., since they also demonstrated very good activity against $C$. jejuni, C. coli, and C. fetus strains isolated in Minas Gerais. As sulfonamides are not indicated for treatment of human or animal campylobacteriosis, they are usually not included in the antimicrobial susceptibility test for Campylobacter 
spp., preventing any comparison with the present results. However, Italian C. jejuni and C. coli showed high rate of resistance to combination sulfamethoxazole plus trimethoprim (GIACOMELLI et al., 2014).

Besides the high rates of resistance to individual antimicrobial agents, the tested Campylobacter spp. strains from animal origin, mainly C. coli and C. fetus, also exhibited a high frequency of multidrug resistance. Considering that C. jejuni and C. coli are naturally resistant to cefoperazone, the erythromycin-tetracycline and nalidixic acid-tetracycline resistance patterns were the most frequent ones amongst the tested C. jejuni and C. coli. Quinolone-tetracycline concomitant resistance has also been described as one of the most prevalent in C. jejuni and C. coli strains from broilers, cattle, ducks, humans, and pigs in China, France, Finland, Italy, Malaysia, and Thailand (HAKANEN et al., 2003; GALLAY et al., 2007; CHEN et al., 2010; ADZITEY et al., 2012; CHOKBOONMONGKOL et al., 2013; DI GIANNATALE et al., 2014; GIACOMELLI et al., 2014). The tested $C$. fetus strains showed cefoperazone-tetracycline as the most common multidrug-resistance profile, taking into account that this species is naturally resistant to nalidixic acid. The present results were different from those observed by Miranda and Lage (2007) and Vargas et al. (2005) for Brazilian C. fetus isolates, which exhibited a low prevalence of multidrug resistant strains, with absence or low observation of resistance to tetracycline. These differences could be explained, considering that the multiple drug resistance observed was higher in C. fetus isolates from feces $(57.14 \%)$ than from genital tract $(28.57 \%)$, and that all C. fetus strains tested by Vargas et al. were from genital origin. Besides, differences in the methodology used or in the origin of the strains could also contribute to the differences detected. Efflux system conferring resistance to several classes of antimicrobials such as tetracyclines, macrolides, fluoroquinolones, and aminoglycosides has been widely described in Campylobacter spp. (GIBREEL; TAYLOR, 2006; FITZGERALD et al., 2008), and could be responsible for the multidrug resistance patterns observed.

In conclusion, it was found that the majority of $C$. jejuni, C. coli, and C. fetus strains isolated from different animal species in Brazil were sensitive to gentamycin, chloramphenicol, and sulfonamides. However, a high proportion of strains showed reduced susceptibility to nalidixic acid, ampicillin, cefoperazone, and tetracycline, antimicrobial agents commonly used for the treatment of human campylobacteriosis. Moreover, the high percentage of multidrug resistant strains observed among C. coli and C. fetus animal isolates confirms the need for continuous monitoring of Campylobacter spp. resistance in the pig and cattle production chains.

\section{Acknowledgments}

CPTB was supported by a scholarship from Coordenação de Aperfeiçoamento de Pessoal de Nível Superior - Capes and APRS, EMSD, and APL were supported by fellowships from Conselho Nacional de Desenvolvimento Científico e Tecnológico - CNPq. This work was supported by the Fundação de Amparo à Pesquisa do Estado de Minas Gerais - Fapemig and CNPq. APL was also supported by Fapemig's Programa Pesquisador Mineiro - PPM (00923-15).

ADVICE FOR TRAVELERS. Treatment guidelines from The Medical Letter, v. 10, n. 118, p. 45-56, 2012.

ADZITEY, F.; RUSUL, G.; HUDA, N.; COGAN, T.; CORRY, J. Prevalence, antibiotic resistance and RAPD typing of Campylobacter species isolated from ducks, their rearing and processing environments in Penang, Malaysia. International Journal of Food Microbiology, v. 154, n. 3, p. 197-205, 2012. doi: 10.1016/j.ijfoodmicro.2012.01.006.

ALVES, T. M.; STYNEN, A. P. R.; MIRANDA, K. L.; LAGE, A. P. Campilobacteriose genital bovina e tricomonose 
genital bovina: epidemiologia, diagnóstico e controle. Pesquisa Veterinária Brasileira, v. 31, n. 4, p. 336-344, 2011. doi: 10.1590/S0100-736X2011000400011.

AVRAIN, L.; HUMBERT, F.; L'HOSPITALIER, R.; SANDERS, P.; VERNOZY-ROZAND, C.; KEMPF, I. Antimicrobial resistance in Campylobacter from broilers: association with production type and antimicrobial use. Veterinary Microbiology, v. 96, n. 3, p. 267-276, 2003. doi: 10.1016/j.vetmic.2003.07.001.

BRASIL. Portaria no 448. UNIÃO, D. O. D. F. Brasilia, DF: Ministério da Agricultura e do Abastecimento, 1998. 38 p.

BURNENS, A. P.; STANLEY, J.; SCHAAD, U. B.; NICOLET, J. Novel Campylobacter-like organism resembling Helicobacter fennelliae isolated from a boy with gastroenteritis and from dogs. Journal of Clinical Microbiology, v. 31, n. 7, p. 1916-1917, 1993.

CARVALHO, A. C. T. Fatores de virulência de amostras de Campylobacter jejuni isoladas de Callithrix penicillata com diarreia. 1992. $81 \mathrm{f}$. Dissertation (Master of Science) - Departamento de Microbiologia, Universidade Federal de Minas Gerais, Belo Horizonte, 1992.

CENTERS FOR DISEASE CONTROL AND PREVENTION (CDC). Trends in Foodborne Illness in the United States, 2013. Atlanta: CDC, 2013.

CHEN, X.; NAREN, G. W.; WU, C. M.; WANG, Y.; DAI, L.; XIA, L. N.; LUO, P. J.; ZHANG, Q.; SHEN, J. Z. Prevalence and antimicrobial resistance of Campylobacter isolates in broilers from China. Veterinary Microbiology, v. 144, n. 1-2, p. 133-139, 2010. doi: 10.1016/j.vetmic.2009.12.035.

CHOKBOONMONGKOL, C.; PATCHANEE, P.; GÖLZ, G.; ZESSIN, K. H.; ALTER, T. Prevalence, quantitative load, and antimicrobial resistance of Campylobacter spp. from broiler ceca and broiler skin samples in Thailand. Poultry Science, v. 92, n. 2, p. 462-467, 2013. doi: 10.3382/ ps.2012-02599.

CHUMA, T.; IKEDA, T.; MAEDA, T.; NIWA, H.; OKAMOTO, K. Antimicrobial susceptibilities of Campylobacter strains isolated from broilers in the southern part of Japan from 1995 to 1999. The Journal of Veterinary Medical Science / The Japanese Society of Veterinary Science, v. 63, n. 9, p. 1027-1029, 2001.

\section{CLINICAL AND LABORATORY STANDARDS} INSTITUTE (CLSI). Performance standards for antimicrobial susceptibility testing - Twenty-second informational supplement. CLSI document M100-S22. Wayne: CLSI, 2012.

CLINICAL AND LABORATORY STANDARDS INSTITUTE (CLSI). Methods for antimicrobial dilution and disk susceptibility testing of infrequently isolated or fastidious bacteria; approved guideline - Second Edition. CLSI document M45-A2. Wayne: CLSI, 2010.

CLINICAL AND LABORATORY STANDARDS INSTITUTE (CLSI). Performance standards for antimicrobial disk and dilution susceptibility tests for bacteria isolated from animals; approved standard Fourth Edition. CLSI document VET01-A4. Wayne: CLSI, 2013a.

CLINICAL AND LABORATORY STANDARDS INSTITUTE (CLSI). Performance standards for antimicrobial disk and dilution susceptibility tests for bacteria isolated from animals - Second Informational Supplement. CLSI document VET01-S2. Wayne: CLSI, 2013b.

DEBRUYNE, L.; GEVERS, D.; VANDAMME, P. Taxonomy of the family. In: NACHAMKIN, I.; SZYMANSKI, C. M.; BLASER, M. J. (Eds.). Campylobacter. Washington: ASM Press, 2008. p. 3-26.

DEKATE, P.; JAYASHREE, M.; SINGHI, S. C. Management of acute diarrhea in emergency room. The Indian Journal of Pediatrics, v. 80 , n. 3, p. $235-246$, 2013. doi: $10.1007 /$ s12098-012-0909-3.

DI GIANNATALE, E.; DI SERAFINO, G.; ZILLI, K.; ALESSIANI, A.; SACCHINI, L.; GAROFOLO, G.; APREA, G.; MAROTTA, F. Characterization of antimicrobial resistance patterns and detection of virulence genes in Campylobacter isolates in Italy. Sensors, v. 14, n. 2, p. 3308-3322, 2014. doi: 10.3390/s140203308.

FOOD AND DRUG ADMINISTRATION (FDA). Summary report on antimicrobials sold or distributed 
for use in food-producing animals - 2010. Silver Spring: FDA, Sep. 2014. Available from: <http://bit.ly/2lBv7nF>. Viewed: 20 Dec. 2015.

FITZGERALD, C.; WHICHARD, J.; NACHAMKIN, I. Diagnosis and antimicrobial susceptibility of Campylobacter species. In: NACHAMKIN, I.; SZYMANSKI, C. M.;BLASER, M. J. (Eds.). Campylobacter. Washington: ASM Press, 2008. p. 227-244.

GALLAY, A.; PROUZET-MAULÉON, V.; KEMPF, I.; LEHOURS, P.; LABADI, L.; CAMOU, C.; DENIS, M.; DE VALK, H.; DESENCLOS, J.C.; MÉGRAUD, F. Campylobacter antimicrobial drug resistance among humans, broiler chickens, and pigs, France. Emerging Infectious Diseases, v. 13, n. 2, p. 259-266, 2007. doi: 10.3201/eid1302.060587.

GARCIA-MIGURA, L.; HENDRIKSEN, R. S.; FRAILE, L.; AARESTRUP, F. M. Antimicrobial resistance of zoonotic and commensal bacteria in Europe: the missing link between consumption and resistance in veterinary medicine. Veterinary Microbiology, v. 170, n. 1-2, p. 1-9, 2014. doi: 10.1016/j.vetmic.2014.01.013.

GIACOMELLI, M.; SALATA, C.; MARTINI, M.; MONTESISSA, C.; PICCIRILLO, A. Antimicrobial resistance of Campylobacter jejuni and Campylobacter coli from poultry in Italy. Microbial Drug Resistance, v. 20, n. 2, p. 181-188, 2014. doi: 10.1089/mdr.2013.0110.

GIBREEL, A.; TAYLOR, D. E. Macrolide resistance in Campylobacter jejuni and Campylobacter coli. Journal of Antimicrobial Chemotherapy, v. 58, n. 2, p. 243-255, 2006. doi:10.1093/jac/dkl210.

HAKANEN, A. J.; LEHTOPOLKU, M.; SIITONEN, A.; HUOVINEN, P.; KOTILAINEN, P. Multidrug resistance in Campylobacter jejuni strains collected from Finnish patients during 1995-2000. The Journal of Antimicrobial Chemotherapy, v. 52, n. 6, p. 1035-1039, 2003. doi: 10.1093/ jac/dkg489.

JONAS, R.; KITTL, S.; OVERESCH, G.; KUHNERT, P. Genotypes and antibiotic resistance of bovine Campylobacter and their contribution to human campylobacteriosis. Epidemiology and Infection, v. 143, n. 11, p. 2373-2380, 2015. doi: 10.1017/S0950268814003410.
JUNTUNEN, P.; OLKKOLA, S.; HÄNNINEN, M. L. Longitudinal on-farm study of the development of antimicrobial resistance in Campylobacter coli from pigs before and after danofloxacin and tylosin treatments. Veterinary Microbiology, v. 150, n. 3-4, p. 322-330, 2011. doi: 10.1016/j.vetmic.2011.02.008.

KINANA, A. D.; CARDINALE, E.; TALL, F.; BAHSOUN, I.; SIRE, J. M.; GARIN, B.; BREUREC, S.; BOYE, C. S.; PERRIER-GROS-CLAUDE, J. D. Genetic diversity and quinolone resistance in Campylobacter jejuni isolates from poultry in Senegal. Applied and Environmental Microbiology, v. 72, n. 5, p. 3309-3313, 2006. doi: 10.1128/ AEM.72.5.3309-3313.2006.

KONKEL, M. E.; JOENS, L. A. Adhesion to and invasion of HEp-2 cells by Campylobacter spp. Infection and Immunity, v. 57, n. 10, p. 2984-2990, 1989.

LAGE, A. P. Estudo das espécies termotolerantes de Campylobacter isoladas de bezerros com e sem diarreia. 1992. 48 f. Dissertation (Master of Science) - Câmara de pós-graduação, Universidade Federal de Minas Gerais, Belo Horizonte, 1992.

LAGE, A. P.; CARVAlHO, A. C. T.; LeITE, R. C. Comparation of procedures for isolating Campylobacter sp. from diarrheic and normal calves. Revista de Microbiologia, v. 23, p. 151-154, 1992.

LAGE, A. P.; LEITE, R. C. Campilobacteriose genital bovina (Vibriose). Pecuária de Corte, v. 10, p. 50-54, 2000.

LASTOVICA, A. J.; ALLOS, B. M. Clinical Significance of Campylobacter and related species other than Campylobacter jejuni and Campylobacter coli. In: NACHAMKIN, I.;SZYMANSKI, C. M. BLASER, M. J. (Eds.). Campylobacter. Washington: ASM Press, 2008. p.123-150.

LEHTOPOLKU, M.; NAKARI, U. M.; KOTILAINEN, P.; HUOVINEN, P.; SIITONEN, A.; HAKANEN, A. J. Antimicrobial susceptibilities of multidrug-resistant Campylobacter jejuni and C. coli strains: in vitro activities of 20 antimicrobial agents. Antimicrobial Agents and Chemotherapy, v. 54, n. 3, p. 1232-1236, 2010. doi: 10.1128/ AAC.00898-09. 
LEITE, R. C. Avaliação de alguns métodos de diagnóstico e análise/custo/benefício do controle da campylobacteriose bovina. 1977. 52 f. Dissertação (Mestrado em Ciência). Departamento de Medicina Veterinária Preventiva, Universidade Federal de Minas Gerais, Belo Horizonte, 1977.

LUANGTONGKUM, T.; MORISHITA, T. Y.; ELTAYEB, A. B.; ISON, A. J.; ZHANG, Q. Comparison of antimicrobial susceptibility testing of Campylobacter spp. by the agar dilution and the agar disk diffusion methods. Journal of Clinical Microbiology, v. 45, n. 2, p. 590-594, 2007. doi: 10.1128/JCM.00986-06.

MAGIORAKOS, A. P.; SRINIVASAN, A.; CAREY, R. B.; CARMELI, Y.; FALAGAS, M.E.; GISKE, C. G.; HARBARTH, S.; HINDLER, J. F.; KAHLMETER, G.; OLSSONLILJEQUIST, B.; PATERSON, D. L.; RICE, L. B.; STELLING, J.; STRUELENS, M. J.; VATOPOULOS, A.; WEBER, J. T.; MONNET, D. L. Multidrug-resistant ,extensively drugresistant and pandrug-resistant bacteria: an international expert proposal for interim standard definitions for acquired resistance. Clinical Microbiology and Infection, v. 18, n. 3, p. 268-281, 2012. doi: 10.1111/j.1469-0691.2011.03570.x.

MIRANDA, K. L.; LAGE, A. P. Antimicrobial susceptibility of Campylobacter sp strains isolated from calves with and without diarrhea in Minas Gerais state, Brazil. Brazilian Journal of Microbiology, v. 38, n. 2, p. 357-362, 2007. doi: 10.1590/S1517-83822007000200032.

OLSON, C. K.; ETHELBERG, S.; VAN PELT, W.; TAUXE, R. V. Epidemiology of Carnpylobacter jejuni infections in industrialized nations. In: NACHAMKIN, I.; SZYMANSKI, C. M.; BLASER, M. J. (Eds.). Campylobacter. Washington: ASM Press, 2008. p. 163-191.

PROGRAMA ESTADUAL DE CONTROLE DE RESÍDUOS DEMEDICAMENTOS VETERINÁRIOSEM ALIMENTOS DE ORIGEM ANIMAL (PAMVET-PR). Levantamento do uso e comercialização de medicamentos veterinários em frango de corte. Paraná: PAMvet-PR, 2005. Available from: <http://bit.ly/2mgXFRP>. Viewed: 24 Feb. 2017.

SAHIN, O.; PLUMMER, P. J.; JORDAN, D. M.; SULAJ, K.; PEREIRA, S.; ROBBE-AUSTERMAN, S.; WANG, L.; YAEGER, M. J.; HOFFMAN, L. J.; ZHANG, Q. Emergence of a tetracycline-resistant Campylobacter jejuni clone associated with outbreaks of ovine abortion in the United States. Journal of Clinical Microbiology, v. 46, n. 5, p. 1663-1671, 2008. doi: 10.1128/JCM.00031-08.

SILVA, J. M. B.; HOLLENBACH, C. B. Fluoroquinolonas $\mathrm{x}$ resistência bacteriana na medicina veterinária. Arquivos do Instituto Biológico, v. 77, n. 2, p. 363-369, 2010.

SILVA, K. C.; KNÖBL, T.; MORENO, A. M. Antimicrobial resistance in veterinary medicine: mechanisms and bacterial agents with the greatest impact on human health. Brazilian Journal of Veterinary Research and Animal Science, v. 50, n. 3, p. 171-183, 2013. doi: 10.11606/ issn.1678-4456.v50i3p171-183.

STYNEN, A. R.; PELLEGRIN, A. O.; FÓSCOLO, C. B.; FIGUEIREDO, J. F.; CANELLA FILHO, C.; LEITE, R. C.; LAGE, A. P. Campilobacteriose genital bovina em rebanhos leiteiros com problemas reprodutivos da microrregião de Varginha - Minas Gerais. Arquivo Brasileiro de Medicina Veterinária e Zootecnia, v. 55, n. 6, p. 766-769, 2003. doi: 10.1590/S0102-09352003000600015.

THRELFALL, E. J.; WARD, L. R.; FROST, J. A.; WILLSHAW, G. A. Spread of resistance from food animals to man - the UK experience. Acta Veterinaria Scandinavica, v. 93, p. 63-68, 2000. Supplement.

TREMBLAY, C.; GAUDREAU, C.; LORANGE, M. Epidemiology and antimicrobial susceptibilities of 111 Campylobacter fetus subsp. fetus strains isolated in Quebec, Canada, from 1983 to 2000. Journal of Clinical Microbiology, v. 41, n. 1, p. 463-466, 2003. doi: 10.1128/ JCM.41.1.463-466.2003.

USUI, M.; SAKEMI, Y.; UCHIDA, I.; TAMURA, Y. Effects of fluoroquinolone treatment and group housing of pigs on the selection and spread of fluoroquinolone-resistant Campylobacter. Veterinary Microbiology, v. 170, n. 3-4, p. 438-441, 2014. doi: 10.1016/j.vetmic.2014.01.036.

VAN DEN BOGAARD, A. E.; STOBBERINGH, E. E. Epidemiology of resistance to antibiotics. Links between animals and humans. International Journal of Antimicrobial Agents, v. 14, n. 4, p. 327-335, 2000. doi: 10.1016/S0924-8579(00)00145-X. 
VARGAS, A. C.; COSTA, M. M.; GROFF, A. C. M.; VIANA, L. R.; KREWER, C. C.; SPRICIGO, D. A.; KIRINUS, J. K. Susceptibilidade antimicrobiana de Campylobacter fetus subsp. venerealis isolado de bovinos. Pesquisa Veterinária Brasileira, v. 25, n. 1, p. 1-3, 2005. doi: 10.1590/S0100736X2005000100001.

WIECZOREK, K.; OSEK, J. Antimicrobial resistance mechanisms among Campylobacter. BioMed
Research International, v. 2013, p. 1-12, 2013. doi: $10.1155 / 2013 / 340605$.

WOO, P. C.; LEUNG, K. W.; TSOI, H. W.; WONG, S. S.; TENG, J. L.; YUEN, K. Y. Thermo-tolerant Campylobacter fetus bacteraemia identified by $16 \mathrm{~S}$ ribosomal RNA gene sequencing: an emerging pathogen in immunocompromised patients. Journal of Medical Microbiology, v. 51, n. 9, p. 740-746, 2002. doi: 10.1099/0022-1317-51-9-740. 